\title{
A Mechanism Analysis of High-tech Enterprise Human Capital Investment for EVA Contribution Based on Gray Relational Analysis
}

\author{
Yeyun Liu, Wei Yu \\ Business School \\ Hu Nan Normal University
}

\begin{abstract}
Integrated innovation is the core competitiveness of high-tech enterprises, which depends on Innovative potential talent. This article makes a quantitative analysis to explore the relationship between high-tech enterprise human capital investment and EVA, using gray correlation analysis method to calculate the contribution of high-tech enterprise human capital investment for EVA. Then the article will demonstration that increasing investment of human capital in high-tech enterprises can help them to create more value.
\end{abstract}

KeyWords-investment in human capital; corporate financial performance; EVA; gray correlation

With the arrival of the knowledge economy and the rapid development of high-tech enterprises, human capital plays a core role in promoting the development of economy. Increasing investment on human resources has a crucial impact on the promotion of enterprise performance and competitive advantage. EVA (Economic Value Added), which economists call "a concept of residual income", is the after-tax net operating profits (NOPAT) minis capital cost. EVA is an economics concept of profit, which is also known as the economic profit (Economic Profit) or economic rents (Economic Rent). As a new index to reflect the enterprise's financial performance, EVA considers not only the cost of debt and equity cost, it tests the real corporate profits from the perspective of shareholders. Recently, many studies have suggested that EVA can reflect enterprise's performance better than traditional accounting index.

\section{The PRESENT Situation Of Human CAPITAL INVESTMENT IN HIGH-TECH ENTERPRISE}

\section{A. The Present Situation of $R \& D$ Funds in High-Tech Enterprises}

In high-tech enterprises, researching and development is the main work for $\mathrm{R} \& \mathrm{D}$ personnel. It is also the most important source of enterprise performance. The fact of R \& $\mathrm{D}$ funds invested in personnel is an essential investment of human capital. In recent years, $\mathrm{R} \& \mathrm{D}$ costs in Chinese high-tech enterprise increase year by year, which we can see from table 1 .

TABLE I. Situation Of LARge And Medium Sized High-Tech EnTERPRise R \& D Funding Investment

\begin{tabular}{l|c|c|c|c|c|c|c|c}
\hline year & 2005 & 2006 & 2007 & 2008 & 2009 & 2010 & 2011 & 2012 \\
\hline projec & & & & & & & & \\
\hline R\&D fund & 363 & 456 & 545 & 655 & 774 & 968 & 1152 & 1288 \\
\hline
\end{tabular}

Source: National Bureau of Statistics, Ministry of Science, <China Statistical Yearbook of high-tech industry>

Similarly, We collect representative high-tech enterprise R \& D in several areas of funding data from the National Bureau of Statistics data, . These data show that some major areas of $\mathrm{R} \& \mathrm{D}$ funding in high-tech enterprises were also increasing year by year and the trend can be seen from Table 2 .

TABLE II. MAJOR AREAS OF LARGE-SCALE HIGH-TECH ENTERPRISE R \& D FUNDING UNIT: 100 MILLION

\begin{tabular}{l|c|c|c|c|c|c|c|c}
\hline \multicolumn{1}{c|}{ year } & 2005 & 2006 & 2007 & 2008 & 2009 & 2010 & 2011 & 2012 \\
$\begin{array}{l}\text { areas } \\
\begin{array}{l}\text { Electronic } \\
\text { information }\end{array}\end{array}$ & 261 & 312 & 393 & 486 & 544 & 539 & 581 & 653 \\
\hline Biomedicine & 45 & 56 & 74 & 87 & 107 & 131 & 154 & 187 \\
\hline Aerospace & 30 & 35 & 44 & 50 & 77 & 103 & 135 & 156 \\
\hline
\end{tabular}

Source: National Bureau of Statistics, Ministry of Science, <China Statistical Yearbook of high-tech industry 


\section{B. The Present Situation of Investment on $R \& D$ Personnel in High-Tech Enterprises}

The number of R \& D staff in high-tech enterprises is growing,this shows that high-tech enterprises pay much more attention to capital investment on introduction, training, and using of high-tech talent. We can find this from table 3 .

TABLE III. SITUATION OF $\mathrm{R} \&$ D PERSONNEL IN LARGE AND MEDIUM SIZED HIGH-TECH ENTERPRISE

\begin{tabular}{l|c|c|c|c|c|c|c|c}
\hline year & 2005 & 2006 & 2007 & 2008 & 2009 & 2010 & 2011 & 2012 \\
\hline $\begin{array}{l}\text { Amount of } \\
\text { personnel }\end{array}$ & 17.3 & 18.9 & 24.8 & 28.5 & 32.0 & 39.9 & 45.6 & 52.1 \\
\hline
\end{tabular}

Source: National Bureau of Statistics, Ministry of Science, <China Statistical Yearbook of high-tech industry>

\section{A MeChanism ANALYSIS OF High-TeCH}

ENTERPRISE HUMAN CAPITAL INVESTMENT FOR EVA

\section{CONTRIBUTION BASED ON GRAY RELATIONAL ANALYSIS}

\section{A. Identifying High-Tech Enterprises}

High-tech enterprises are economic entities which ransform continuous research and development then form the core of independent intellectual property rights, and take this as the foundation to carry out business activities. According to the Ministry of science and technology, Ministry of finance, the State Administration of Taxation in 2008 April jointly issued the "management measures," that the high-tech enterprises and the "support of national key high-tech fields", standard of high-tech enterprise as follows [1]:

TABLE IV. High-TECH ENTERPRISE CERTIFICATION STANDARDS

\begin{tabular}{|c|c|}
\hline High-tech areas & High-tech enterprise certification standards \\
\hline $\begin{array}{l}\text { 1,the electronic information } \\
\text { technology } \\
2, \quad \text { bio-medicine and new } \\
\text { technologies } \\
\text { 3, aerospace technology } \\
\text { 4.new material technology } \\
\text { 5, high-tech services } \\
\text { 6,new energy and energy-saving } \\
\text { technology } \\
\text { 7, Resource and Environmental } \\
\text { Technology } \\
\text { 8,high technology to transform } \\
\text { traditional industries }\end{array}$ & $\begin{array}{l}\text { (1)registered enterprises in China (excluding Hong Kong, Macao and Taiwan regions), } \\
\text { which own independent intellectual property rights; } \\
\text { (2) products (services) are in the <supported by the state high-tech fields> the specified } \\
\text { range; } \\
\text { (3) personnels that have a university degree or above scientific and technical accounted } \\
\text { for } 30 \% \text { of total number of workers, in which R \& D staff of enterprises accounted for } \\
10 \% \text { of total number of employees } \\
\text { (4) companies in order to get scientific and technical new knowledge and creative } \\
\text { application of new scientific and technological knowledge so that doing continuing } \\
\text { research and development activities, and research and development expenses accounted } \\
\text { for the proportion of total sales revenue during the recent three years total meet the } \\
\text { following requirements: } \\
\text { a. sales in recent year is less than } \$ 50 \text { million, rate is not less than } 6 \text { percent } \\
\text { b. sales in recent year is between } \$ 50 \text { million and } 20,000 \text { yuan, ,rate is not less than } \\
4 \text { percent } \\
\text { c. sales in recent year is not less than } 20,000 \text { yuan, ,rate is not less than } 3 \text { percent } \\
\text { Among them, research and development expenses of the enterprises in the Chinese } \\
\text { territory to total proportion is not less than } 60 \% \text {. Companies incorporated for less than } \\
\text { three years, calculated according to the actual operating life; } \\
\text { (5) high-tech product revenue of enterprise accounted for more than } 60 \text { percent of } \\
\text { annual gross revenue; } \\
\text { (6) indexes that the level of organization, management of corporate research and } \\
\text { development, scientific and technological achievements into the ability, the number of } \\
\text { independent intellectual property right are in line with <high-tech enterprise } \\
\text { management guidelines> requirements }\end{array}$ \\
\hline
\end{tabular}

B. A Mechanism of High-Tech Enterprise Human Capital Investment for Eva Contribution Based on Gray Relational Analysis

A. gray relational analysis method

The reasons for selecting the gray correlation method is mainly based on the following:

The data for research in this article is from listing corporation annual report data of high-tech enterprises. High-tech enterprises in China have a wide distribution area and range. It is hard to collect all the listing Corporation annual report data of the country's high-tech enterprises, and small sample study may result in data loss, and sampling may cause data distortion phenomenon. The gray relation model can solve this problem, it is applicable for the case that quantity of samples and the number of samples have no rules.

Some researchers have used gray relational analysis to find the relationship between human capital investment and economic growth, enterprise production and performance. These confirmed that human capital investment had an essential effect on economic growth and enterprise performance. We can see the gray correlation model becomes gradually mature in this field. 
A mechanism of high-tech enterprise human capital investment for EVA contribution Based on gray relational analysis

This paper uses the gray relational degree analysis to calculate the relational degree of human capital investment and high-tech enterprise EVA, and then draw the contribution of human capital investment for high-tech firms of EVA. Selecting index of investment in enterprise human capital

In this paper, the enterprise human capital investment are divided into four categories:

The investment of staff allocation (investment of introducing personnel): Investment of enterprises on staff recruitment, selection, and post deployment and other aspects ,including advertising, recruitment network recruitment, headhunting services, booth, selection (the test and examination etc.), travel allowance and the maintenance and development of new staff investment costs.

The investment of staff education and training investment (education investment): The expenses of enterprises on education and training, including access to knowledge and technology and pre-job training on-the-job training, pay and off-the-job training etc..

The investment of employees incentive (using personnel investment): including the salary; enterprise for additional subsidies special types of work or position to develop, motivate employees to give full play to the work creativity (allowances and subsidies); and in order ironment, such as: medical care, recreation, infirmary staff, holiday tour, to encourage employees to improve labor efficiency to reward employee performance part of the excess labor (bonus).

The investment of employee insurance benefit (investment of keeping personnel): Including not only statutory social insurance payment, but also benefit activities in enterprises which are to motivate employees to improve work efficiency and build harmonious work envpsychological counseling, labor protection and other incentive payment.

Using EVA as a measure of financial performance indicators

$\mathrm{EVA}=$ net profit after tax - cost of capital $=$ net profit after tax- the total amount of the capital $*$ the weighted average cost of capital rate

$$
\begin{gathered}
E V A=N O P A T-W A C C \times T C \\
W A C C=R s \frac{E}{T C}+R d \frac{D}{T C}(1-T)
\end{gathered}
$$

Among them:

NOPAT: net operating profit after tax, is after-tax profit obtained in the case that does not involve company's capital structure .and is all capital after-tax return on investment.
TC: the total capital, is the total capital invested in the process of production and operation, including debt capital and equity capital.

WACC: rate of weighted average capital cost , is calculated per costs by unit weight unit cost of debt capital and equity capital according to the debt and equity in the capital structure .

$\mathrm{E}$ is for equity capital; $\mathrm{D}$ is bond capital; $\mathrm{T}$ is income tax rate; $\mathrm{Rd}$ bond capital cost rate, which refers to pre-tax unit of debt capital cost; Rs is the cost of equity capital ratio, refers to the necessary return rate of equity investors demand. What most common is to use the capital asset pricing model (CAPM) to determine .

$\mathrm{Rs}=\mathrm{Risk}$ free rate $*$ The risk premium on the market portfolio

$$
\mathrm{Rs}=\mathrm{Rf}+\beta \times(\mathrm{Rm}-\mathrm{Rf})
$$

Where: Rf: the risk-free rate, can be used in the longest duration of Treasury internal rate of return. Because circulation of national debt market scale is small. We use 5 year bank deposit of the internal rate of return" instead.

$\mathrm{Rm}$ : The average market risk premium; $\beta$ : reflect risk factor that enterprise stock return rate relative to the stock market over the same period, the value of $\beta$ is greater, the risk that the enterprise stock has a higher system risk, then required rate of return is higher. The value of $\beta$ can be obtained by regression calculate the enterprise stock returns on contemporaneous stock market index returns .

Rm-Rf: The risk premium on the market portfolio ,is premium that the stock market relative to the risk-free rate of return .

c. analysis of action mechanism on contribution of human capital investment in high-tech enterprise to EVA

Based on Cobb-Douglas production function and the contribution of the human capital investment theory of output production function found by later scholars. This article analyses the mechanism of human capital investment in high-tech enterprises on EVA, and the trail like follows:

Firstly, the index of human capital investment is divided into four parts: investment of the allocation; investment of staff education and training; the investment in the employee salary; insurance investment

Then analysis method to calculate the contribution to EVA and the order that four kinds of human capital investment to EVA the contribution of human capital in high-tech enterprises, while the high-tech enterprises is divided into eight areas, and then get the order of the contribution on EVA from each high-tech enterprise human capital input sequence. Mechanism of the structure chart of this study are as follows: 


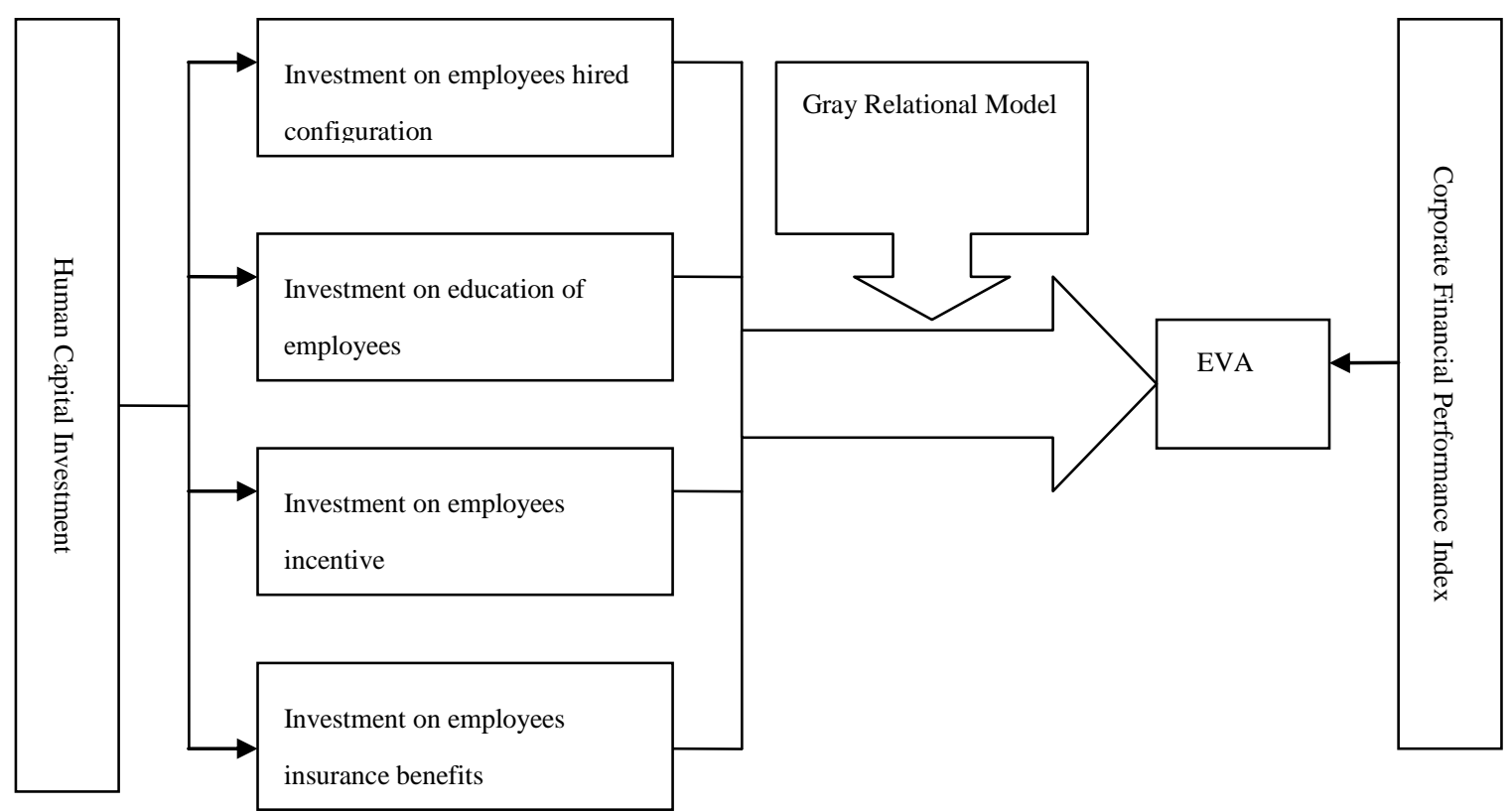

Figure 1

In a word, through the effect analysis that different human capital investment method to performance of high-tech enterprise, we can find an effective method for high-tech enterprises on human capital investment, and to eliminate unnecessary sunk cost human capital so that improve enterprise performance.

\section{REFERENCE}

[1] Ministry of Science and Technology, Ministry of Finance, State Taxation Administration. management approach for high-tech enterprises. April ,2008 jointly issued
[2] Hal Varian, Zhou Hong [Interpret], Microeconomics (Advanced Tutorial) [M].Economic Science Press, 1997:52-84.

[3] Colombo Massimo, Grilli Luca. Founder's human capital and the growth of new technology-based firms: A competence-based view [J]. Research Policy, 2005, 134(6): 795-816.

[4] Mason A. Carpenter, Wm. Gerard Sanders and Hal B.Gregersen. Bundling human capital with organizational context: the impact of international assignment experience on multinational firm performance and CEO pay [J].Academy of Management Journal, 2001, 44(3):493-511. 